\title{
THE IMPACT OF POLITICS ON FISCAL BEHAVIOR: THE CASE OF BRAZIL*
}

\author{
Werner Baer $\$$ \\ Donald V. Coes ${ }^{\infty}$
}

\begin{abstract}
RESUMO
Este artigo examina a proposição de que um governo que está enfrentando uma eleição ou que depende de um apoio popular para governar terá dificuldade de resistir ao aumento de gastos ou de aumentar os impostos. Os conseqüentes déficits fiscais podem ser financiados pelo Banco Central, o que resulta em inflação, ou pelos empréstimos domésticos e/ou estrangeiros, aumentando a dívida doméstica ou estrangeira. Depois de um curto resumo histórico da experiência brasileira, um método quantitativo está sendo utilizado para testar a validade desta hipótese de uma maneira mais formal.
\end{abstract}

Palavras-chave: déficit fiscal, política, inflação, dívida, regressão robusta.

\begin{abstract}
This paper examines the proposition that a government which faces an election or depends on general popular support to govern effectively will find it difficult to resist increasing expenditures or to raise taxes. The resulting fiscal deficits are then either financed by the central bank, which produces inflation, or by domestic and/or foreign borrowing, increasing the government's foreign or domestic debt. After a brief historical survey of Brazil, a method is use to test the validity of this hypothesis in a more formal way.
\end{abstract}

Key words: fiscal deficits, politics, inflation, debt, robust regression.

JEL classification: E62, O42, O54.

* We would like to thank Pallab Mozumdar, Peri Silva, and two anonymous referees for thoughtful criticisms and suggestions.

$\S$ University of Illinois at Urbana-Champaign. Department of Economics -University of Illinois - 1407 West Gregory Drive Urbana, Illinois, 61801 - USA. Fone: (217) 333 8388.E-mail: wbaer@uiuc.edu.

a University of New Mexico.

Recebido em junho de 2004. Aceito em julho de 2005. 


\section{INTRODUCTION}

It is a well-known proposition that a government which faces an election or which depends on general popular support to govern effectively will find it difficult both to resist increasing expenditures or to raise taxes. The resulting fiscal deficits are then either financed by the central bank, which produces inflation and a variety of accompanying distortions, or by domestic and/or foreign borrowing, increasing the government's foreign and/or domestic debt. In this paper we examine this proposition as it applies to Brazil from the mid-twentieth century to the first years of the twenty-first century. After a brief historical survey of this relationship in Brazil, we develop and apply a method to test the validity of this hypothesis in a more formal way. The nearly six decades covered here permit this proposition to be examined in the context of both authoritarian military and democratic governments.

\section{THE CIVILIAN GOVERNMENTS: $1950-1964$}

The democratically elected Getúlio Vargas government of the early 1950 s relied on a number of populist measures to gain political support. Its main economic thrust was to take a nationalist stance on such issues as the control over the exploitation of natural resources (resulting in the creation of Petrobras, the state firm that had the monopoly in finding and exploiting oil resources). Although the Vargas administration was officially committed to the maintenance of a degree of price stability, when election time came Vargas opted for a wage policy which contradicted this goal. ${ }^{2}$ Increasing economic constraints, among them a sharp fall in export earnings beginning in 1954 and concern among business groups with the government's wage policies, narrowed Vargas' options. His decision to authorize a 100 percent increase in the minimum wage was a clear choice for a populist position and a rejection of the positions of business leaders, senior military officers, and conservative political opponents. Skidmore found that Vargas' "...mixed approach to economic policy-making was political, inspired by the need to maintain wide congressional and electoral support. But for the problem of inflation...(his government).could not devise any mixture of orthodoxy and nationalism." By mid-1954 Vargas' political position was untenable, as the opposition mobilized support against him.

The interregnum between the suicide of Vargas in August 1954 and the election and inauguration of Juscelino Kubitschek in March 1956 consisted of attempts to re-establish a conservative economic policy. Eugenio Gudin, a severe critic of the "developmentalist" policies of Vargas, became Finance Minister, and tried to follow an orthodox anti-inflationary policy. He attempted to control the monetization of the government deficit and to put a break on credit expansion. Although Gudin's policies were well viewed by the international financial community, he was not successful in obtaining substantial amounts of credits from the IMF or the US government or from the private financial sector. The austerity measures which Gudin continued to follow resulted in a liquidity crisis that caused the collapse of two banks, large scale bankruptcies, a drastic decline in capital formation, and exchange controls on the exporting sector. ${ }^{4}$ The general discontent of many economic sectors forced Gudin out of office.

\footnotetext{
See, for example, Dornbusch and Edwards (1991).

Besserman Vianna in Abreu (1990, p. 148).

Skidmore (1967, p. 111). See also Villela and Besserman Vianna, in Giambiagi et al. (2005, p. 21-44).

The exchange controls ("confisco cambial") consisted of forced sales of foreign exchange earnings to the government at a rate below the market value of those earnings.

5 Pinho Neto in Abreu (1990, p. 156-157).
} 
The interim government appointed a more politically pliable finance minister, José Maria Whitaker. A strong defender of the coffee sector interests, he soon eliminated the exchange controls. He also eased monetary policies and wanted to balance this by suspending the government's coffee purchasing program. This led to violent protests from the coffee sector. A plan to reform exchange rate policies was never approved, which ultimately led Whitaker to resign. Skidmore concluded that the Finance Ministry “...simply did not have under its control total government expenditure (there were semi-autonomous government agencies whose budgets could not be cut back by the Finance minister on short notice)." $\mathrm{He}$ also favored an easing of credit restrictions to the productive sector. The interregnum years can thus be seen as a tentative initial turn towards economic orthodoxy that could not be sustained politically, followed by a forced return to "softer" policies that accommodated various economic interest groups.

The Juscelino Kubitschek administration (1956-60) accelerated the import substitution industrialization policies of Vargas and, in addition, decided to build the new capital, Brasília. These projects of the Kubitschek period, often characterized as "desenvolvimentismo" (developmentism) were popular with a large part of the population. ${ }^{8}$ The fiscal and monetary implications of these large and expensive projects were considered to be of secondary importance, in part because their macroeconomic consequences were less obvious than the highly visible projects themselves. ${ }^{9}$ The reluctance of the government to raise the prices of the services provided by various state enterprises was also important in increasing the budget deficits of this period. Another aggravating factor was the government's yielding to pressure from the coffee sector to purchase surplus production in an era of falling prices. Finally, political pressures made it made it impossible to contain the growing public sector payroll. As a result, monetization of the increasing deficit tripled the inflation from 14.4 to 42.8 percent between 1958 and $1959 .^{10}$

Although some stabilization attempts were made in the late $1950 \mathrm{~s}$, the political necessities of carrying on the various desenvolvimentista projects of the government, of finishing the construction of the new capital, while maintaining current expenditures, resulted in the continued growth with growing inflation. "With respect to public expenditure Skidmore found that Kubitschek "...was most reluctant to sanction any attempts at real austerity measures." 12

The period 1961 to 1964 was characterized by political tumult which, in turn, caused economic chaos. Janio Quadros, a reformer, had been elected president with one of the largest majorities in the country's history, but resigned suddenly eight months into his mandate. During his eight months in office Quadros made a determined effort to deal with inflation. He simplified the multiple exchange rate system, reduced many subsidies for imports, tightened credit and instituted a wage freeze. Entrenched resistance to many of the proposed reforms and Quadros' inability to form strategic alliances to overcome the opposition, however, were among the main reasons for his resignation.

Quadros' resignation was followed by months of uncertainty over his successor, as various roadblocks were placed by the military and by the conservative opposition in the path of the vice-

6 Skidmore (1967, p. 161).

7 Ibid, p. 162-163.

8 Skidmore insightfully found that the "...success of Kubitschek's economic policy was the direct result of his success in maintaining political stability. He was able to do so only by a political tour de force. The secret lay in Kubitschek's remarkable ability to find something for everyone, while avoiding any direct conflict with his enemies." (ibid, p. 167).

9 The monetary mechanism through which a number of these projects were financed is described by Orenstein and Sochaczewski in Abreu (1990, p. 184-186). See also Villela in Giambiagi et al. (2005, p. 45-68).

10 Source: Fundação Getúlio Vargas, Índice Geral dos Preços-Disponibilidade Interna, cited in Abreu (1990).

11 Orenstein and Sochaczewski in Abreu (1990, p. 189-91).

12 Skidmore (1967, p. 178).

13 For details, see Baer and Kerstenetzky, in Roett (1972, p. 113-114). 
president João Goulart as the successor. Once he was allowed to take over the presidency, Goulart proved to be weak, vacillating in his support for radical reformist forces and more conservative groups. During the political turmoil of that period fiscal and monetary control was lost, as economic policy became totally subordinated to political struggles. ${ }^{14}$

Once confirmed in power, Goulart proved to be weak president. He made half-hearted attempts at stabilization, which were soon abandoned when he could not resist the demand of labor leaders for rapid wage adjustments. Pressures from other directions came from the demands of the business community to refrain from painful credit restrictions, as well as from other quarters not to abandon inflationary subsidized exchange rates for the import of petroleum and wheat, and not to readjust public utility rates. Budget deficits increased and the rate of inflation grew to 50 percent and finally in 1964 to yearly rates of close to 100 percent. A combination of economic and political turmoil finally resulted in a military coup on March 31, 1964.

\section{THE MILITARY GOVERNMENTS}

\section{a) Stabilization without political pressure}

The military governments that took charge in 1964 would last until 1985. The first three administrations were relatively immune from populist pressures, while the last two were more sensitive to the impact of their economic policies on the public. The first military government, led by General Humberto Castello Branco, immediately formulated a short-run economic program, called PAEG, ${ }^{15}$ which was aimed at controlling inflation and correcting distortions that had developed as a result of the long period of import substitution industrialization (ISI) and inflation. With the passage of power to the succeeding military government of General Artur da Costa e Silva in 1967, most of these stabilization measures were maintained. Among them were the curtailment of government expenditures, increases in revenues through improved tax collection mechanisms, and real wage repression. The fact that this was a military government, which could overcome the opposition of various types of interest groups to its policies and that it was backed by U.S. economic assistance and multilateral institutions like the World Bank, made it relatively easy to implement its policy package. ${ }^{16}$ Also helpful was a new constitution which was drawn up in 1966 and approved in 1967. This new constitution strengthened the federal government's control over public expenditures.

As a result of these policies real government revenues rose by 25 percent in 1965, while real wages declined. Credit tightening was so strong that total real credit available in the mid- and later sixties was below that of the earlier part of the decade. In addition, subsidies on the import of petroleum and wheat were eliminated, public utility rates were raised, and efforts were made to modernize financial markets. ${ }^{18}$ Policymakers were aware that despite the short-run pain that these measures created for a number of socio-economic groups, the ultimate result would be to increase savings, which policy makers assumed would flow into the most efficient sectors.

14 Interviews with a number first-hand observers of the politics of this period and the subsequent period of military government are given in Dines, Fernandes and Salomão (2000). For a first hand view of the events in this period by the U.S. ambassador to Brazil during the Goulart government and the early years of the military regime, see Gordon (2001).

15 Programa de Ação Econômica do Governo (1964).

16 Skidmore (1988, ch. 2).

17 Under this new constitution the Congress could neither originate a spending bill nor increase one proposed by the government. See Skidmore (1988, p. 56).

18 For details, see Baer and Kerstenetzky in Roett (1972, p. 117-8). 
The impact of these policies was a significant decline in government expenditures as a proportion of GDP: government consumption fell from 13.4 in 1963 to 11.5 percent in 1968; government salaries from 8.3 to 7.6 percent; subsidies from 1.7 to 1.1 percent; and total government purchases from 17.4 to 15.6 percent. Tax revenues rose from 18 to 26.7 percent of GDP. ${ }^{19}$ Real minimum monthly wages in São Paulo declined by 16.8 percent between 1963 and 1968, with a decline of 16.5 percent in Rio de Janeiro in the same period.

\section{b) The hard-line military regime}

Most of the policies of the first two military governments were carried out without any overt political resistance. This was only possible in one of the most repressive political environments in modern Brazilian history. Shortly after their rise to power, the military ministers effectively subordinated the 1946 Constitution to an emergency "Institutional Act", which granted extraordinary powers to the executive. This act effectively stripped Congress of any real role in determining government expenditures.

Stirrings of opposition among civilian politicians, as well as a developing division between the more moderate ("castellista") military and their hard-line ("linha dura") fellow officers led to a further hardening in 1968, as the latter faction in the military predominated. Institutional Act $\mathrm{N}^{\circ}$ 5, which dramatically curtailed the remnants of the democratic system, was passed in December. It permitted an even greater degree of freedom to formulate economic policy without any opposition. ${ }^{21}$ President Costa e Silva used his new powers to revise tax policy. A constitutional amendment, masterminded by Finance Minister Delfim Netto, reduced from 20 to 12 percent the constitutionally designated share of the federally collected taxes distributed to state and municipal governments. ${ }^{22}$

The third military government, under the presidency of General Emílio G. Medici, benefited from the groundwork had been laid to promote growth policies without returning to the previous high levels of inflation. Monetary, credit and fiscal policies became more growth-oriented. Notable was an easing of credit for agriculture and consumer purchases. Credit for housing construction was made available. There also gradually evolved an elaborate system of tax incentives to promote exports, investment in backward regions, and the development of capital markets. A recently developed system of indexing financial instruments made it possible for the government to finance budget deficits in a non-inflationary manner and thus to increase expenditures on infrastructure projects. Wage policies were maintained to keep costs, and thus inflationary pressures, under control. This was possible due to the continued repressive nature of the military regime. Skidmore observes that "...no interest group or social sector could hope to gain by bringing pressure in the public arena (behind the scenes was obviously another matter). The technocrats were still at the helm and they had clear sailing."

19 Maneschi in Roett (1972, p. 189). Lara Resende in Abreu (1990, p. 224), examined changes in the structure of government expenditures: he found that the great proportional increase in the budget was for the military - rising from $5.8 \%$ of the government expenditure in 1964 to $10.4 \%$ in 1965 while expenditures for the Labor Ministry declined from $2.9 \%$ to $1.9 \%$, and would continue to fall to $1 \%$ in 1966 . Social security expenditures, which stood at $7 \%$ in 1965 , fell to $5.5 \%$ in 1967. Huge declines were also experienced by the Transportation ministry.

20 Skidmore (1988, Ch. IV).

21 Roett (1992), notes that Institutional Act No 5 “...empowered the president to recess the national Congress, state legislative as semblies, and municipal councils by Complementary Acts. These bodies would convene again only when called by the president. In addition, the president could decree intervention in the states in the national interest, without regard for the constitutional restrictions on intervention; he could suspend political rights of any citizen for ten years and cancel election mandates without regard for constitutional limitations." (p. 136).

22 Skidmore (1988, p. 89).

23 Skidmore (1988, p. 138). For greater details of this period, see Corrêa do Lago in Abreu (ch. 10). The politics of the military government and the tensions between the "castellista" and "linha dura" factions are extensively discussed in Gaspari (2002, 2003). 
military governments, was a long period of high economic growth. From 1968 until 1974 Brazil's GDP grew at an annual rate of 10.1 percent, with industry growing at yearly rates of 12.2 percent. This came to be called the "milagre econômico" (Brazilian Miracle) by the supporters of the government, giving the military an apparent justification for its economic and political policies.

\section{c) The military regimes under gradual political reopening}

The administration of General Ernesto Geisel, who took office at the beginning of 1974, was a return to the more moderate "castellista" faction of the military, which had generally viewed the 1964 intervention as a necessary but temporary departure from democratic government. As such, it was committed to a gradual political opening. The new government was also committed to an improvement of the highly skewed distribution of income. ${ }^{25}$ All this occurred during the dramatic oil price revolution engineered by OPEC, which quadrupled the price of oil. As Brazil at the time was still dependent on imports for 80 percent of its oil needs, it faced two options. The oil price increase required either a substantial transfer of resources to the oil-exporting countries or a sharp fall in the rate of economic growth in net oil importers like Brazil. The latter option was not politically acceptable to the Geisel administration, which needed growth in order to promote equity and to win the support of the population in its planned gradual political opening. The growth option was made feasible through borrowing from international banks, which had accumulated a large amount of "petrodollars" and were anxious to lend out their deposits to favored borrowers, among them emerging economies like Brazil. ${ }^{26}$

Geisel opted for debt-led growth. The Second National Development Plan was introduced in 1975. It called for a huge investment program focusing on import substitution of basic industrial goods (steel, aluminum, copper, fertilizers and petrochemicals) and capital goods, and the rapid expansion of the economic infrastructure (hydro and nuclear power plants, alcohol production for the automobile fleet, transportation and communications). Many of these investments were undertaken by state enterprises. As a result of these policies, state enterprise expenditures as a percent of GDP rose from 9.8 in 1970 to 17.9 in 1975 and 30.1 percent in 1980. Gross foreign debt rose from US\$ 17 billion in 1974 to US $\$ 61$ billion in 1981. At the same time the government's attitude towards the pricing of goods and wage adjustments was increasingly permissive, which contributed to a rise of inflation through out the 1970 s and 1980s. ${ }^{27}$

The last military government, headed by General João Figueiredo, began its mandate trying to stabilize the economy. But strong resistance to restrictive policies from various sectors and the fact that slowing growth was perceived to make the political opening more difficult, soon led to a policy reversal. Throughout the first half of the 1980s various attempts were made to control inflation (such as the elimination of tax incentives, increases in public utility tariffs, limits to credit expansion, etc.). None of these measures were followed through due to political pressures from many sectors, which were heightened by the announced goal of returning power to a civilian government. $^{28}$

24 Baer in Roett (1976, p. 46-51); Baer (2001, p. 75-77); Coes (1995, p. 51-54).

25 The worsening of Brazil's income distribution had been criticized by the president of the World Bank. This had substantially diminished the pride of the regime in achieving a number of years of high economic growth.

26 For greater details, see Baer (2001, ch. 6); Coes (1995, p. 17-22).

27 Baer (2001, p. 122-130).

28 For details see Baer (2001, p. 95-98). 


\section{THE POST-MILITARY CIVILIAN REGIMES}

\section{Sarney, Collor, and Franco}

The inflation of the last military government continued to grow under the first civilian government of President José Sarney. He introduced the heterodox Cruzado Program in a drastic attempt to kill the country's hyperinflation. The program consisted of the introduction of a new currency and a price freeze. At first, the virtually instantaneous disappearance of inflation dramatically increased Sarney's popularity. The effectiveness of the Cruzado Plan was gradually eroded as no measures were taken to make an underlying fiscal adjustment and as Sarney refused to make any corrective price adjustments. The latter policy resulted in dramatic price distortions as the evasion of price controls rapidly spread throughout the economy. Both the lack of a fiscal adjustment and the refusal to loosen the price freeze were motivated by the political situation. The congress scheduled to be elected in November 1986 was also to be a constitutional convention, while Sarney was anxious to have his term extended by an additional year. He thus was opposed to any adjustment in frozen prices, which he perceived as having been crucial in his past popularity, and he was also opposed to the fiscal measures necessary to consolidate price stability over the longer run. ${ }^{29}$ Once Sarney had achieved his political goals in the November 1986 election, the Cruzado stabilization program was abandoned and Brazil was again subjected to hyperinflation. None of the subsequent attempts at stabilization, including a number of price freezes, succeeded. The political cost of fiscal adjustment was unacceptable to Sarney in the post-Cruzado period, as it also was to his successors, Presidents Fernando Collor and Itamar Franco.

A complicating situation in the late 1980s and in the 1990s was the new 1988 Constitution. One of its sections called for the automatic transfer of a substantial portion of federal tax receipts to the states and municipalities, without at the same time transferring some government expenditure obligations. This made the budget balancing task even more difficult than before. ${ }^{3}$

\section{The Real Plan: success and failure}

Brazil's Real stabilization program was introduced in July 1994. Developed by economists and policy makers under the leadership of Finance Minister Fernando Henrique Cardoso, who was subsequently elected President in late 1994, it dramatically halted the hyperinflation. Inflation fell from about 50 percent a month in June of that year to 0.97 percent in September. The introduction of the new currency was preceded during several months by the use of an accounting pseudo-currency and by a temporary fiscal adjustment. ${ }^{32}$ The latter consisted of a number of temporary tax increases and some modest spending cuts. Even though price stability was maintained (in part through a more open economy with a fixed exchange rate anchor), permanent fiscal adjustment was not achieved. In fact, the fiscal situation of the government deteriorated from $1995 \mathrm{on}$. The operational budget balance, which includes the impact of real interest repayments on the debt, moved from a surplus of 0.5 percent of GDP in 1994 to a deficit of -8.4 percent of GDP in 1998. The primary balance also deteriorated, moving from a surplus of 4.3 percent of GDP in 1994 to a deficit

29 The political pressures on the Sarney government, and the options for politically low-cost stabilization programs in Brazil and in other Latin American countries in this period are examined in Weyland (2002).

30 Baer (2001 ch. 9); Coes (1995 chs. 5 and 6).

31 Giambiagi et al. (1999).

32 For details, see Baer (2001, ch. 10). 
of 0.1 percent of GDP in 1998. The main reason for the deterioration of the primary balance was the failure of the government to limit the rise in expenditures at every level of government. The political ambitions of President Cardoso to pass a constitutional amendment to enable him to run for a second term - and once passed to win a second term - meant that his administration was unable to implement badly needed reductions in expenditures on personnel. As a result, the number of public employees remained stubbornly high and their real wages continued to climb. ${ }^{33}$

The financing of expanding public sector deficits was made possible by the maintenance of very high interest rates to secure voluntary private lending to the government. With the fall in both actual and expected inflation, the real interest rate increased sharply. The situation was aggravated both internally, with the continuing failure to pass basic fiscal reforms, and externally, with the Asian financial crises in 1997 and the Russian crisis in 1998. As a result, the operational deficit, which is the basic primary deficit plus the real costs of servicing the public debt, rose from 3.9 percent of GDP in 1966 to an alarming 8.4 percent in 1998.

The government thus found itself in a vicious circle. To maintain the exchange rate and to finance its deficit it had to borrow at a rising real interest rate, which in turn worsened the fiscal situation. As this potentially unsustainable situation became more apparent to potential lenders, investor confidence was further undermined, putting additional pressure on real interest rates. The result was that the sum of payments for interest and amortization rose from 14.7 percent of government expenditures in 1994 to 24.4 percent in 1998. Without an offsetting rise in the primary surplus, the operational deficit of the government rose, adding to the stock of public debt. The success of the Plano Real gave the government enough credibility to facilitate the non-central bank financing of the deficit for a considerable amount of time. Thus fiscal adjustment could be postponed for a long time. As the debt of the government mounted and fiscal adjustment was constantly postponed, however, the credibility of the government gradually eroded. The international financial crises of 1997-98 accelerated the endgame of the plan and led to the devaluation of January 1999.

Despite the increasing macroeconomic pressures arising both internally and externally, the success of the Real Plan in its first several years gave Cardoso an easy victory in his quest for a second presidential term in the October 1998 election. With the election behind them, policymakers had the political space to make greater fiscal adjustments than in the past. This became even more urgent with the impact of the devaluation of January 1999 on public finances. As much of the federal debt was linked to the exchange rate, the public sector primary surplus had to be raised from $0.5 \%$ of GDP in 1998 to $3.25 \%$ in 1999. In the period 2000-2002 interest rates had to be kept high to help finance the current account deficit, and to prevent an accelerated outflow of capital. This trend in interest rates, plus the accelerated devaluation in 2002, increased the burden of the debt further. By the end of 2002 the debt reached almost 60 percent of GDP, and necessitated an even higher primary surplus, which reached 3.75 percent of GDP in 2002.

\section{The election of Lula}

The 2002 presidential election matched the outgoing government's candidate, José Serra, against Luis Ignácio Lula da Silva of the Workers' Party (Partido dos Trabalhadores), whom Cardo-

33 Baer (2001, p. 205-207). Also, the failure to rapidly implement reform of the civil service pension system meant that pension costs rose rapidly as a proportion of total public sector personnel costs. Pension expenditures in the late $1990 \mathrm{~s}$ represented around 43\% of total public sector personnel expenditures, having risen from around 35\% in 1992. Influencing this rise was the increase in the minimum wage in 1995 , which rose $43 \%$ in nominal terms, while inflation was only $15 \%$; this was applied to the benefits paid in the government's pension system.

34 Although a number of efforts were made during the second Cardoso administration to reduce growth of the public sector debt by containing the growth of expenditures, most of the improvement can be attributed to a growth in tax revenue. Over the 1998-2002 period, nominal expenditure growth reported by the National Treasury grew at about 3.0 percent monthly, while revenues increased at about 3.8 percent. 
so had easily defeated in 1998. The initial success of the Plano Real in ending high inflation was considerably more distant from the electorate, however, and polls even in early 2002 showed that the task of electing the government's candidate would be difficult. As it became apparent to international financial markets that Lula had a good prospect of election to the presidency, the value of the real declined significantly, moving from about 2.4 per dollar to 3.8 by the time of the first round of elections in October. This reaction of financial markets was largely motivated by the position of Lula in earlier tries for the presidency, when he questioned the necessity of repayment of the public debt. He and most of his moderate supporters in the PT took pains to change this image during the 2002 campaign, and he was elected in the second round with about 60 percent of the vote, the largest in Brazilian political history.

\section{THE LINK BETWEEN POLITICAL PRESSURES AND FISCAL POLICY, 1947-2004}

The central proposition of this paper is that much of the variation in Brazilian macroeconomic policy over the past half-century reflects the changing political pressures on the government. Over much of the period, these pressures in the short run centered on output growth and the maintenance of employment, even at the longer run risk of fiscal disequilibrium arising from the financing costs of the public sector's deficit. These pressures were clearly greater at times when the government believed it needed to broaden its political support or acquire greater legitimacy, and waned during periods of authoritarian government or after clear electoral successes. Although it is easy with hindsight to criticize what may appear to be a myopic focus on the short run, this "imediatismo", as some Brazilians have characterized it, may have had a political, if not economic, justification.

It is of course far easier to state this proposition than it is to evaluate it in a more analytical or quantitative way. If the apparent association between political pressure and fiscal policy did in fact underlie much of Brazil's recent economic history, however, this relation should be visible over the long period of our study. In this section we present the results of a formal test that suggests that there was indeed a highly significant association between political pressure and macroeconomic policy over this period.

The 58 years from 1947 through 2004 do not provide obvious continuous measures of either political pressure or the macroeconomic stance of successive governments. They do, however, permit the rough classification of the period into categories that reflect these two variables. This is the approach taken here, in which we employ a rules-based classification procedure to characterize each year in two different ways: (1) by the degree to which the political pressures on the government can were low, moderate, or high; and (2) by the expansionary fiscal stance of the government, similarly classified as low, moderate, or high.

A formal rules-based classification was employed in order to avoid subjectivity in the assignment of levels for the political and fiscal variables in a given year. In brief, this procedure used a number of criteria defined ex ante to classify a year as "high", "moderate", or "low" with respect to the two variables. For the political variable, for example, an extra-constitutional or unscheduled change in the Presidency, or a rate of real GDP growth at least 5 percent below the preceding two years resulted in a "high" (=3) political pressure classification. Conversely, the absence of any presidential change or rates of growth of real GDP at least 1 percent above the average of the preceding two years resulted in a "low" $(=1)$ classification, with intermediate cases giving a "moderate" $(=2)$ classification. 
A rules-based procedure was implemented in a parallel way for the fiscal variable. A public sector borrowing requirement (PSBR) in excess of 3 percent of GDP, for example, was sufficient to classify a year as one of "high" expansionary fiscal policy. In earlier years, for which PSBR data do not exist, the classification rules employed measures of the federal deficit as a percent of GDP. A full explanation of the way in which the rules-based procedure was used for both variables over the 58 year period is provided in the Appendix.

One obvious consequence of the rules-based classification procedure when applied to nearly six decades of annual data is that the link between political and fiscal pressures in Brazil may have changed. Our procedure formally tests for this possibility by including a trend variable in the tests whose results we report below. Another serious potential difficulty with a time series-based analysis like that of this study is that of serial correlation. This arises from the fact that periods of high or low political and fiscal pressure are likely to continue over more than one year, so that the 58 annual observations are not temporally independent, potentially compromising significance tests. Our procedure used a robust regression technique to deal with this potential problem. ${ }^{35}$ Finally, it might be argued that a simple three level classification of the variables into "high", "moderate" and "low" categories is too crude. For this reason, we provide below the results of our test using a finer classification.

Table 1 presents the results of the political and fiscal pressure classifications for the period from 1947 through 2004. As an illustration of how the classifications were made, we focus on three different, widely separated years. In 1954 the Vargas government faced increasing political pressures, as the criticism by political opponents that subsequently ended with his suicide in August of that year steadily mounted. These pressures were exacerbated by a sharp fall in export earnings and a near doubling of the rate of inflation. Compared to other years of this decade, or even with the whole period, our criteria rank the degree of political pressure as "high". Fiscal policy, however, was not clearly expansionary, with the federal government budget at about half a percent of GDP, slightly lower than in several other years of the Vargas government, and well below that of the later Kubitschek government. In the absence of the more informative measures of fiscal policy available in later periods, we rank the fiscal variable as "moderate" in 1954.

Table 1 - Political and economic pressure and degree of expansionary fiscal policy

\begin{tabular}{|c|c|c|c|}
\hline Political Pressure> & Low & Moderate & High \\
\hline \multicolumn{4}{|l|}{ Fiscal Pressure } \\
\hline \multirow[t]{2}{*}{ Low } & $\begin{array}{l}\text { 1948, 1952, 1968, 1971, } \\
1972,2004\end{array}$ & $\begin{array}{l}1947,1951,1966,1969, \\
1970,1973,1974,1976, \\
1977,1978,1979,2002\end{array}$ & 1991, 1994 \\
\hline & (6 years) & (12 years) & (2 years) \\
\hline \multirow[t]{2}{*}{ Moderate } & $1949,1957,1958$ & $\begin{array}{l}\text { 1950, 1953, 1960, 1965, } \\
1967,1986,1995,1996, \\
1997,2000\end{array}$ & $\begin{array}{l}\text { 1954, 1955, 1959, 1961, } \\
\text { 1963, 1975, 1980, 1981, } \\
\text { 1982, 1983, 1985, 1992, } \\
1993,2001,2003\end{array}$ \\
\hline & ( 3 years) & (10 years) & (15 years) \\
\hline \multirow[t]{2}{*}{ High } & (No cases) & (No cases) & $\begin{array}{l}\text { 1956, 1962, 1964, 1984, } \\
\text { 1987, 1988, 1989, 1990, } \\
\text { 1998, 1999 }\end{array}$ \\
\hline & & & (10 years) \\
\hline
\end{tabular}

35 See, for example, Draper and Smith (1998). 
Two decades later, the new government headed by General Geisel, a proponent of the less repressive "castellista" branch of the military, took office. Shortly afterward, the consequences of the sharp rise in the international price of petroleum forced a fall in GDP growth rate, which had averaged more than 11 percent in 1973 and 1974, to a 5.2 percent annual rate. Application of the rules-based procedure outlined above therefore ranks 1975 as a year of "high" political pressure, the first such year during the period of military rule that began in 1964. Fiscal policy, however, continued to be moderately contractionary. The federal government budget deficit was a modest 0.35 percent of GDP, with net public sector saving at nearly 5 percent of GDP. Our classification rules accordingly rank 1975 as a year of "moderate" fiscal expansionary policy.

In 1985 José Sarney, vice presidential candidate in 1984, assumed office in place of the deceased President-elect, Tancredo Neves. Throughout his presidency and that of his two successors, Brazil's return to civilian, electoral-based rule significantly increased the political pressure on its leaders. These pressures were increased by a sharp acceleration in the rate of inflation, the failure of the first of Brazil's stabilization programs in late 1986. As was shown earlier, the last years of this decade were among the worst in Brazil's long inflationary experience, with the annual rate exploding from about 140 percent in 1986 to over 2700 percent in 1990. Our classification rules thus rank 1987, as they do for all of the remaining years of the Sarney, Collor, and Franco governments, as one of "high" political pressure.

Fiscal policy in these years was marked by a virtual absence of control during the remaining years of the Sarney government (until 1990), resulting in a rule-based classification of "high" fiscal pressure for the 1987-90 period. In 1991, the first full year of the new Collor government, there was an apparent tightening of fiscal policy. This was rather artificial, however, since it was accomplished through the suspension of interest payments on public debt, delays in payments to government suppliers, and a once-and-for-all tax on financial assets. Despite the long-run inviability of this form of fiscal tightening, the resulting temporary fall in the PSBR translates to a "low" level of fiscal pressure, using our ranking procedure.

Even a cursory examination of Table 1 would suggest a positive association between political and fiscal pressure. Due to the frequent presence of serial correlation over the 58 year period, however, simple tests of association (such as Chi-square) would tend to exaggerate the degree of significance. In addition, as noted earlier, there is a possibility that the degree of association between the two qualitative variables as defined here may have changed over the period.

In order to avoid the difficulties of statistical interpretation that these problems pose, an "ordered logit" robust regression procedure was used here to test for the significance of the apparent association between political pressure and fiscal pressure. This approach models the relationship as one in which greater political pressure leads to a more expansionary fiscal stance. Since the two variables are discrete (three levels for each variable in our basic model), rather than continuous, shifts in the explanatory variable (political pressure) are hypothesized to produce corresponding discrete shifts in the dependent variable (fiscal expansion), which are measured by changes in the regression intercepts. The "robust" regression procedure was used to obtain estimates of the standard errors that reflect the presence of serial correlation that would otherwise compromise interpretations of significance. Table 2 reports the estimates for the basic model, with no time trend and three levels (low, moderate, and high) for each of the two variables.

36 For details on these fiscal policies, see Baer (2001, p. 178-182). 
Table 2 - Ordered logit estimates of the political-fiscal pressure relationship: basic model

\begin{tabular}{lcc}
\hline & Coefficient & Robust Standard Error \\
\hline Political pressure & $1.587^{* * *}$ & 0.383 \\
Intercept 1 & 2.582 & 0.879 \\
Intercept 2 & 5.394 & 1.056 \\
\hline Number of observations: 58 & & Pseudo R $\mathrm{R}^{2}: 0.15$ \\
\hline Log-likelihood: & -50.520 & Wald test of overall significance: $17.20(0.000)^{* * * *}$ \\
\hline
\end{tabular}

The estimates for the basic model support the hypothesis of a significant relationship between political pressure and the level of fiscal expansionary stance, with a significant coefficient both for the political pressure variable and for the overall regression. Neither intercept is significant, however, suggesting that there is no significant omitted variable bias.

As an additional check on the estimates above, two variants on the basic model were estimated, with the results reported in Table 3. In the model reported in Table 3.a, a time trend was added to the basic model of Table 2 to test for the possibility that the relationship between political pressure and the fiscal stance may have been time-dependent. The coefficient for this variable is not significant, however, with the results of the basic model little changed. We interpret this result to imply that there is no evidence that the relationship between political and fiscal pressure altered significantly over the period we studied.

The second extension, reported in Table 3.b, was estimated using four levels of political pressure, rather than three, in order to see if the basic conclusions of our study were sensitive to a change in the fineness or coarseness of the classification procedure and in the critical points used to assign a year to a particular category of political pressure. The modification of the classification rules that produced four levels of political pressure ("high", "moderate-high", "moderate-low", and "low") is given in the Appendix. As may be seen from Table 3.b, even with this modification our conclusions remain virtually unchanged.

Table 3 - Ordered logit estimates of the political-fiscal pressure relationship: extensions

\section{Extension a: Estimate with time trend}

\begin{tabular}{lcc}
\hline & Coefficient & Robust Standard Error \\
\hline Political pressure & $1.569^{* * *}$ & 0.387 \\
Year & 0.005 & 0.014 \\
Intercept 1 & 2.670 & 0.953 \\
Intercept 2 & 5.485 & 1.111 \\
\hline Number of observations: 58 & & Pseudo R': 0.15 \\
\hline \multirow{2}{*}{ Log-likelihood: } & -50.477 & \multirow{2}{*}{ Wald test of overall significance: $16.85(0.000)^{* * * *}$} \\
\hline
\end{tabular}


Extension b: Estimate with four levels of political pressure (with no time trend)

\begin{tabular}{lcc}
\hline & Coefficient & Robust Standard Error \\
\hline Political pressure & $1.996^{* * *}$ & 0.530 \\
Intercept 1 & 3.703 & 1.261 \\
Intercept 2 & 6.748 & 1.443 \\
\hline Number of observations: 58 & \multicolumn{2}{c}{ Pseudo R $\mathrm{R}^{2}: 0.19$} \\
\hline Log-likelihood: $\quad-47.805$ & Wald test of overall significance: $14.18(0.000)^{* * * *}$ \\
\hline
\end{tabular}

\section{CONCLUSION}

Our examination of Brazil's economic history in the second half of the twentieth century shows how difficult it is for a government of an emerging country to establish fiscal discipline through a curtailment of expenditure. If the party that governs depends on elections to continue to be in power, it is extremely difficult for it to resist pressures to spend. ${ }^{37}$ In Brazil this was not only the case during periods of democracy, but also during that period during which the military government began plans to open up the political system. Effective control over the growth of fiscal expenditures was only possible during the period of military rule in which there were no plans for opening up the political system.

Governments that increased expenditures without similar increases in revenues could either cover the resulting budget deficits by borrowing from the Central Bank (i.e., using inflationary financing) or by borrowing abroad (i.e. increasing the country's foreign indebtedness). The latter way out was only possible when the government had the confidence of the international financial community. Brazil's ability to use this option varied considerably over the past five decades, with a significant increase in access to world capital markets beginning in the late 1960s. Access fell sharply when Latin American borrowers fell into disfavor following Mexico's moratorium in the early 1980s. Subsequent changes in Brazil's international borrowing ability were highly influenced by events in other emerging market economies, heightening Brazilians' sense of vulnerability to international market conditions. Brazil's successful economic stabilization under the Cardoso government and orderly transition of political power to Lula in 2002 contributed significantly to restoring its access to world capital markets.

\section{REFERENCES}

Abreu, Marcelo de Paiva (ed.). A ordem do progresso: cem anos de política econômica republicana 1889-1989. Rio de Janeiro: Editora Campus, 1990.

Ames, Barry. The deadlock of democracy in Brazil. Ann Arbor: The University of Michigan Press, 2001.

Baer, Werner. The Brazilian economy: growth and development. $5^{\text {th }}$ edition. Westport, CT: Praeger, 2001.

Coes, Donald V. Macroeconomic crises, policies, and growth in Brazil, 1964-90. Washington, D.C.: The World Bank, 1995.

37 Our analysis corroborates the study of Ames (2001) who found that “... Since the early $19^{\text {th }}$ century, Brazilian politics has centered on politicians' attempt to fill bureaucratic jobs with their allies and to supply individualized and geographically specific political goods, what Americans call pork barrel, to supporters. Without question, political support is exchanged for government jobs and public works in every society, but Brazil is unique in the pervasiveness of these exchanges and their tendency to substitute for broader, more ideologically or programmatically driven policy-making...” (p. 23-24) 
Dines, Alberto; Fernandes Jr., Florestan; Salomão, Nelma (orgs.). Histórias do poder: 100 anos de política no Brasil. Vol. I-III. São Paulo: Editora 34 Ltda., 2000.

Dornbusch, Rudiger; Edwards, Sebastian. The macroeconomics of populism in Latin América. Chicago: University of Chicago Press/NBER, 1991.

Draper, Norman R.; Smith, Harry. Applied regression analysis. $3^{\text {rd }}$ ed. New York: J. Wiley \& Sons, 1998.

Gaspari, Elio. A ditadura envergonhada (2002); A ditadura escancarada (2002); A ditadura derrotada (2003). São Paulo: Companhia das Letras.

Giambiagi, Fabio; Moreira, Maurício Mesquita (eds.). A economia brasileira nos anos 90. Rio de Janeiro: BNDES, 1999.

Giambiagi, Fabio; Villela, André; Barros de Castro, Lavinia; Hermann, Jennifer (orgs.). Economia brasileira contemporânea (1945-2004). São Paulo: Editora Campus, 2005.

Gordon, Lincoln. Brazil's second chance. Washington, DC: Brookings Institution, 2001.

Roett, Riordan (ed.). Brazil in the sixties. Nashville, Tennessee: Vanderbilt University Press, 1972.

Roett, Riordan (ed.). Brazil in the seventies. Washington, D.C.: American Enterprise Institute for Public Policy Research, 1976. 1992 .

Brazil: politics in a patrimonial society. Fourth edition. Westport, Connecticut: Praeger,

Skidmore, Thomas E. Politics in Brazil 1930-1964: an experiment in democracy. New York: Oxford University Press, 1967.

. The politics of military rule in Brazil, 1964-85. New York: Oxford University Press, 1988.

Weyland, Kurt G. The politics of market reform in fragile democracies: Argentina, Brazil, Peru, and Venezuela. Princeton: Princeton University Press, 2002.

\section{APPENDIX A: ClASSIFICATION RULES FOR CHARACTERIZING THE LEVELS OF POLITI- CAL AND FISCAL PRESSURE}

The rules-based procedure employed to make the estimates presented in Section 5 was implemented in order to avoid subjective and arbitrary characterizations of given years as ones of "high", "moderate", or "low" political pressure or fiscal expansionary stance. A variety of political and macroeconomic data were used to produce these classifications.

Political pressure: Several criteria, some of them purely political and others economic conditions which could plausibly be assumed to affect the level of political pressure on the government, were employed to produce the political pressure variable. For a "high" (=3) political pressure classification, one or more of the following criteria had to be satisfied:

Rule 1: A non-scheduled change in the presidency or an extra-constitutional change. Examples of such years were 1954 (Vargas' suicide), 1964 (military coup), or 1985 (death of Presidentelect Tancredo Neves and assumption of the presidency by the Vice-presidential candidate, José Sarney).

Rule 2: Annual growth of real GDP of 1.5 percent or less. Brazil's average annual GDP growth rate was about 5 percent in the period of our study. Annual growth of less than a third of that was assumed to place high political pressure on the government. In the period of our study, this first occurred in 1963 (0.6 percent growth). In another example, in 1988, GDP growth was actually negative (-0.1 percent). 
Rule 3: A slowing of the growth rate of GDP in relation to the average of the two preceding years of 5 or more percent. This rule resulted in several years being classified as ones of "high" political pressure even if they would otherwise be "moderate" or "low" years by other criteria. Examples occurred during the Kubitschek government in 1956, when growth slowed from the 8.3 annual average of the preceding two years to 2.9 percent, or in 1975, when the first petroleum shock pushed the growth rate nearly 6 percent below the average of 1973 and 1974.

Rule 4: A level of inflation significantly greater than contemporary expectations. Since Brazil introduced a widespread system of indexation in the mid-1960s, which ended in 1994, three different sub-periods were used to implement this rule. In the 1947-66 sub-period, "high" inflation (and hence high political pressure) was assumed to be a 20 percent increase over the preceding year. For the 1967-94 sub-period, the increase was assumed to be 50 percent or more. In the 1995-2004 period, the critical level was a 10 percent or greater increase in the rate of inflation.

"Moderate" and "low" levels of political pressure were defined in an analogous way. Under Rule 1 (presidential change), "moderate" pressure $(=2)$ was assumed when there was a change in presidency through election or death or other incapacity (other than suicide). "Low" (=1) political pressure under Rule 1 was assumed when there was no change in the presidency. Under Rule 2 (GDP growth), "moderate" political pressure was the result of an annual rate of growth between 1.5 and 5 percent. "Low" political pressure under Rule 2 was GDP growth of 5 percent or more.

"Moderate" and "low" political pressure rankings under Rule 3 (change in the GDP growth rate from the preceding two year average) resulted respectively from a change in the growth rate of between 5 and 1 percent below the preceding years, and from a change of no more than 1 percent below the preceding years (or an actual increase in the growth rate of GDP, relative to the preceding two year average). The years of the "milagre economico" of the early 1970s, when GDP growth rates were high and accelerating, provide good examples of "low" political pressure rankings under both Rule 2 and Rule 3.

As was the case for "high" political pressure rankings due to changes in inflation, three different sub-period rules were used. In the pre-indexation period (1947-66), "moderate" political pressure was assumed when inflation rates were between 5 and 20 percent higher than the preceding year, while "low" pressure resulted from either a fall in the rate of inflation or no more than a 5 percent rise relative to the preceding year. In the sub-period of extensive indexation (1967-94) the respective criteria were a 10 to 50 percent increase in the rate ("moderate") and a 10 percent or lower increase or actual fall in the rate ("low"). Examples of "low" political pressure due to a fall or to very small rises in the inflation rate were the late 1940s, due in part to an overvalued exchange rate. The same effect was operative between 1995 and 1999, when the exchange rate was used as a price anchor.

As was noted in Section 5, our basic model was extended to four levels of political pressure to test for the robustness of our conclusions to changes in the critical points that produced the rankings. Although this extension did not result in any change, the modifications in the criteria that were used to produce a four-level ranking ("high", "moderate/high", "moderate/low", and "low”) are noted here for completeness. "High" political pressure under Rule 1 (presidential change) corresponded to a major non-scheduled change or extra-constitutional change. A "moderate/high" ranking under Rule 1 resulted when there was a change in presidency due to election or death or incapacity in office, while a "moderate/low" ranking resulted from a change in the presidency due to military consensus or the re-election of a civilian president. Finally, a "low" ranking under Rule 1 occurred when there was no change in the presidency. 
Rule 2 (GDP growth rate) rankings corresponded respectively to rates that were negative ("high" political pressure), positive but less than 3 percent ("moderate/high), between 3 percent and 5 percent ("moderate/low") and greater than 5 percent. Rule 3 (change in GDP growth rate) rankings resulted respectively from GDP growth at least 6 percent below the average of the two preceding years ("high" political pressure), between 6 and 2 percent below the preceding years' average ("moderate/high"), between 2 percent below and 1 percent above ("moderate/low") and GDP growth at least 1 percent above that of the preceding two years ("low”).

Implementation of Rule 4 (change in inflation) in the four level case split the "moderate" category ( 5 to 20 percent higher than preceding year) into 5 to 10 percent and 10 to 20 percent higher in the pre-indexation period (1947-66). In the extensive indexation period (1967-94), the moderate category (10 to 50 percent increase) was split into 10 to 25 percent and 25 to 50 percent ranges. Finally, in the post-Real Plan period after the ending of indexation (1995-2004), the "moderate" category (2 to 10 percent above the preceding year) was split into 2 to 7 percent and 7 to 10 percent.

Fiscal pressure: Modern measures of the fiscal stance of the federal government in Brazil have only been available since 1981, when the government began to report several measures of the public sector borrowing requirement (PSBR). In preceding years, less satisfactory estimates of the federal fiscal stance are based on the surplus (deficit) as a percent of GDP, using national accounts data. After 1970, information on net public sector saving, a more inclusive concept, may be also used as a supplementary check. ${ }^{38}$

In this study, a ranking of a "high" degree of federal fiscal expansionary pressure was assigned in the 1947-1980 period when the federal fiscal deficit as a percent of GDP was 3 percent or greater. The three years in this period ranked as "high" by this criterion were 1956, 1962, and 1964. From 1981 on, when PSBR data is available, a federal operational PSBR of 3 percent of GDP was used to assign a "high" ranking. Such rankings occurred in the late 1980s, as the Sarney government lost control of federal finances, and again in 1998 and 1999, as the Cardoso administration permitted a substantial fiscal expansion to be financed through foreign borrowing.

A "moderate" fiscal ranking in the 1947-80 period was assigned when the federal deficit was between 0.25 and 3.0 percent of GDP, while a "low" ranking resulted from a federal surplus or from a deficit of no more than 0.25 percent of GDP. In the 1981-2004 period, a "moderate" fiscal pressure ranking was given when the federal PSBR was between 0.5 and 3.0 percent of GDP, and a "low" one when the PSBR was less than 0.5 percent of GDP.

38 Use of these data did not change any of the fiscal rankings in this study, and are therefore not reported here. 